\title{
UJI EFEKTIVITAS EKSTRAK DAUN PEPAYA (Carica papaya L.) TERHADAP PERTUMBUHAN BAKTERI Escherichia coli DAN Staphylococcus aureus
}

\author{
Maria Tuntun \\ Jurusan Analis Kesehatan, Polteknik Kesehatan Tanjungkarang \\ Email: maria_tuntun@yahoo.com
}

\begin{abstract}
Effectiveness of the Leaf Extract of Papaya (Carica papaya L.) on bacterial Growth: Escherichia coli and Staphylococcus aureus. Carica papaya is widely used as a traditional medicine society. Papaya leaves contain antibacterial compounds such as tannins, alkaloids, flavonoids, terpenoids, saponins and alkaloids karpain. Escherichia coli and Staphylococcus aureus are bacterial pathogen that frequently infects in humans. This study was to know ability of the leaf extract of papaya to inhibit the bacterial growth: $E$. coli and $S$. aureus and determine the effective inhibition concentration. The study was a laboratory experiment. "Kirby Bauer" diffusion method agar were used to inhibition test. Variable of this study were concentration of the leaf extract of papaya $(10 \%-100 \%)$ and the growth inhibition zone of E. coli and S. aureus. Data were analyzed by ANOVA. The results showed that F value $>\mathrm{F}$ table, both of bacteria: E. coli and $S$. aureus. It showed that the leaf extract of papaya (Carica papaya L.) had an influence on the bacteria growth, but did not effective than positive control: Chlorampenicol $30 \mathrm{mcg}$.
\end{abstract}

Keywords: Papaya, Escherichia coli, Staphylococcus aureus

\begin{abstract}
Abstrak: Uji Efektivitas Ekstrak Daun Pepaya (Carica papaya L.) Terhadap Pertumbuhan Bakteri Escherichia coli dan Staphylococcus aureus. Daun pepaya banyak digunakan masyarakat sebagai obat tradisional. Daun pepaya mengandung senyawa antibakteri seperti tanin, alkaloid, flavonoid, terpenoid, saponin, dan alkaloid karpain. Bakteri Escherichia coli dan Stapylococcus aureus merupakan bakteri pathogen yang sering menginfeksi manusia. Tujuan penelitian untuk mengetahui kemampuan ekstrak daun pepaya (Carica papaya L.) dalam menghambat pertumbuhan bakteri Escherichia coli dan Staphylococcus aureus dan mengetahui konsentrasi ekstrak daun pepaya (Carica papaya L.) yang efektif dalam menghambat pertumbuhan bakteri Escherichia coli dan Staphylococcu aureus. Jenis penelitian adalah eksperimen laboratorium. Uji daya hambat menggunakan metode difusi agar cara Kirby Bauer. Variabel penelitian yaitu konsentrasi ekstrak daun pepaya 10\%-100\%, dan zona hambat pertumbuhan bakteri Escherichia coli dan Staphylococcus aureus. Analisa data menggunakan uji Anova. Hasil penelitian ini didapatkan F hitung > F tabel, baik terhadap bakteri Escherichia coli maupun bakteri Staphylococcus aureus, hal ini menunjukkan bahwa ekstrak daun pepaya (Carica papaya L.) mempunyai pengaruh terhadap pertumbuhan bakteri tersebut, tetapi tidak efektif jika dibandingkan dengan zona hambat antibiotik Chlorampenicol $30 \mathrm{mcg}$ (kontrol positif)
\end{abstract}

Kata kunci: Daun pepaya, Escherichia coli, Staphylococcus aureus

Pepaya (Carica papaya L.) merupakan tumbuhan perdu yang berbatang tegak dan basah. Hampir semua bagian tanaman pepaya dapat dimanfaatkan, seperti daun, batang, buah dan akarnya. Pepaya merupakan salah satu tanaman yang digunakan dalam pengobatan tradisional. Bagian tanaman ini yang sering digunakan sebagai obat tradisional adalah daunnya, karena mengandung enzim papain (Tim Karya Tani Mandiri, 2011).

Daun pepaya mengandung senyawasenyawa kimia yang bersifat antiseptik, antiinflamasi, antifungal, dan antibakteri. Senyawa antibakteri yang terdapat dalam daun pepaya diantaranya tanin, alkaloid, flavonoid, terpenoid, dan saponin (Duke, 2009). Selain itu daun pepaya mengandung zat aktif seperti 
alkaloid carpaine, asam-asam organik seperti lauric acid, caffeic acid, gentisic acid, dan asorbic acid, serta terdapat juga $\beta$ - sitosterol, flavanoid, saponin, tannin, dan polifenol (Duke, 2009).

Secara tradisional daun pepaya dimanfaatkan oleh masyarakat dalam mengatasi penyakit diare dan mengobati penyakit kulit seperti jerawat. Penyakit diare dapat disebabkan oleh bakteri, diantaranya bakteri Escherichia coli, sedangkan penyakit kulit seperti jerawat dapat disebabkan oleh bakteri Stapylococcus aureus. Bakteri Escherichia coli dan Stapylococcus aureus merupakan bakteri pathogen yang sering menginfeksi manusia.

Bakteri Escherichia coli merupakan penyebab penyakit diare akut yang diderita oleh semua usia. Bakteri Escherichia coli menghasilkan toksin yang dapat melekat dan merusak sel-sel mukosa usus halus. Gejala klinis yang paling sering terjadi dalam kasus infeksi ini antara lain diare berair, kram perut, demam ringan, mual, dan rasa tidak enak badan. Bakteri Escherichia coli diklasifikasikan oleh ciri khas sifat-sifat virulensinya dan setiap grup menimbulkan penyakit melalui mekanisme yang berbeda, antara lain EPEC, EHEC, ETEC, EIEC dan EAEC (Jawetz, 2008).

Bakteri Staphylococcus aureus merupakan penyebab terjadinya infeksi yang bersifat piogenik. Infeksi yang disebabkan oleh bakteri ini biasanya timbul dengan tandatanda khas yaitu peradangan, nekrosis, dan pembentukan abses, serta dapat menyebabkan berbagai macam infeksi seperti pada jerawat, bisul, atau nanah. Bakteri Staphylococcus aureus kemampuannya berkembangbiak dan menyebar luas dalam jaringan tubuh serta adanya beberapa zat ekstraseluler yang dapat diproduksi S. aureus dapat menimbulkan berbagai penyakit (Jawetz, 2008)

Zat antibakteri adalah zat yang dapat mengganggu pertumbuhan atau bahkan mematikan bakteri dengan cara mengganggu metabolisme bakteri. Antibakteri hanya dapat digunakan jika mempunyai sifat toksik selektif, artinya dapat membunuh bakteri yang menyebabkan penyakit tetapi tidak beracun bagi penderitanya. Faktor-faktor yang berpengaruh pada aktivitas zat antibakteri adalah $\mathrm{pH}$, suhu stabilitas senyawa, jumlah bakteri yang ada, lamanya inkubasi, dan aktivitas metabolisme bakteri (Jawetz, 2008).

Zat aktif antibakteri dalam daun pepaya telah diuji terhadap beberapa bakteri, secara in vitro diantaranya terhadap bakteri Proteus mirabilis yang menghasilkan zona hambat 7,00 mm pada konsentrasi $1000 \mu \mathrm{g} / \mathrm{disk}$ (Yusha'u, et all 2009), Staphylococcus epidermidis dengan diameter zona hambat sebesar 19,8 mm (Ardina 2007), Klebsiella pneumonia dengan MIC (Minimal Inhibition Concentracion) pada konsentrasi $25 \mu \mathrm{l}, 50 \mu \mathrm{l}$, dan $75 \mu \mathrm{l}$ (Suresh, 2008), bakteri Shigella dysenteriae dengan KHM 18\% v/v dan KBM 20\% v/v (Bobby, 2012).

Tujuan penelitian ini yaitu mengetahui konsentrasi efektif ekstrak daun pepaya dalam menghambat pertumbuhan bakteri Escherichia coli dan Staphylococcus aureus. Manfaat penelitian ini daharapkan mejadi database tentang kemampuan antibakteri yang terdapat dalam ekstrak daun pepaya (Carica papaya L.) dalam menghambat pertumbuhan bakteri Escherichia coli dan Staphylococcus aureus secara invitro.

\section{METODE PENELITIAN}

Penelitian ini bersifat eksperimen laboratorium, yaitu untuk mengetahui efektivitas antibakteri ekstrak daun pepaya (Carica papaya L.) terhadap pertumbuhan bakteri Escherichia coli dan Staphylococcus aureus. Uji daya hambat menggunakan metode difusi agar cara Kirby Bauer.

Dalam penelitian ini menggunakan daun pepaya dengan kriteria: daun pepaya tua yang segar dan masih berwarna hijau, yang diambil pada tangkai ke 5 dan 6 dari pucuk paling bawah. Daun pepaya ini dibuat simplisia dan dibuat ekstrak etanol dengan cara maserasi. Konsentrasi ekstrak etanol daun pepaya dibuat mulai dari $10 \%, 20 \%, 30 \%, 40 \%, 50 \%, 60 \%, 70 \%, 80 \%$, $90 \%$, dan $100 \%$. Bakteri uji yaitu strain murni Escherichia coli dan Staphylococcus aureus yag didapatkan dari laboratorium Mikrobiologi Fakultas Kedokteran Universitas Indonesia.

Penelitian ini dilakukan di laboratorium Bakteriologi Laboratorium Terpadu Politeknik Kesehatan Tanjungkarang, pada bulan JuliSeptember 2014. Determinasi daun pepaya dilakukan di laboratorium Botani Jurusan biologi FMIPA Universitas Lampung untuk memastikan varietas dari daun pepaya yang digunakan.

Alat yang digunakan: autoclave, inkubator, hot plate, oven, petridisk (diameter $10 \mathrm{~cm}$ ), tabung reaksi panjang $(20 \mathrm{~cm})$, tabung reaksi pendek $(10 \mathrm{~cm})$, disk cakram steril, pipet volume, pipet ukur, labu ukur, erlenmeyer, pipet tetes, corong glass, waterbath, rak tabung, beaker glass, lampu spiritus, kapas, lidi kapas steril, jarum ose, kertas saring, aluminium foil, kertas kopi, lap, dan kertas tempel. 
Bahan/ media yang digunakan: media Muller Hinton Agar (MHA), media Brain Heart Infusion Broth (BHIB), NAS, aquadest steril, $\mathrm{NaCl} 0,85 \%$, etanol teknis $96 \%$.

Pembuatan simplisia daun pepaya: dimulai dengan memilih daun pepaya sesuai kriteria, yaitu daun pepaya segar yang berwarna hijau tua sebanyak 5,0 kg dicuci bersih dengan air mengalir. Kemudian daun pepaya dipotongpotong, lalu dijemur di bawah sinar matahari secara tidak langsung sampai kering. Simplisia diblender hingga halus menjadi serbuk (Gunawan, 2004). Pembuatan ekstrak etanol daun pepaya dilakukan dengan cara maserasi.

Prosedur uji daya hambat dengan teknik difusi metode Kirby Bauer dilakukan dengan cara memulaskan suspensi bakteri pada media Muller Hinton Agar sampai seluruh permukaan tertutup sempurna, lalu diletakan diatasnya disk blank yang telah direndam pada larutan ekstrak daun pepaya dengan masing-masing konsentrasi, yaitu $100 \%, 90 \%, 80 \%, 70 \%, 60 \%, 50 \%, 40 \%, 30 \%$, $20 \%$, dan $10 \%$. Lalu diinkubasi pada suhu $37^{\circ} \mathrm{C}$ selama 24 jam dalam inkubator. Zona hambat yang terbentuk ditandai dengan tidak adanya pertumbuhan bakteri disekitar disk. Zona hambat diukur dengan zona reader dalam satuan $\mathrm{mm}$ (Soemarno, 2000). Setiap perlakuan diulang sebanyak tiga kali. Suspensi bakteri yang digunakan setara dengan Mc Farland 1. Untuk kontrol negatif menggunakan disk blank yang direndam aquadest steril sedangkan kontrol positif menggunakan disk antibiotik Chloramphenicol $\quad 30 \mu \mathrm{g}$. Disk blank yang digunakan dalam penelitian ini berdiameter 6,0 $\mathrm{mm}$.

Pengolahan data dimulai dengan uji normalitas dan homogenitas varian untuk mengetahui apakah terdapat data yang berbeda secara bermakna. Jika memenuhi syarat $(p>0,05)$ maka dilanjutkan dengan uji ANOVA untuk melihat perbedaan secara bermakna dua kelompok atau lebih pengaruh konsentrasi ekstrak daun pepaya terhadap pertumbuhan bakteri Staphylococcus aureus dan bakteri Escherichia coli. Jika hasil uji ANOVA didapatkan $p<0,05$, maka dilanjutkan dengan uji beda nyata terkecil (BNT) untuk melihat adanya perbedaan antar perlakuan.

\section{HASIL}

Hasil uji daya hambat ekstrak daun pepaya (Carica papaya L.) terhadap pertumbuhan bakteri Staphylococcus aureus dapat dilihat pada grafik batang dibawah ini.

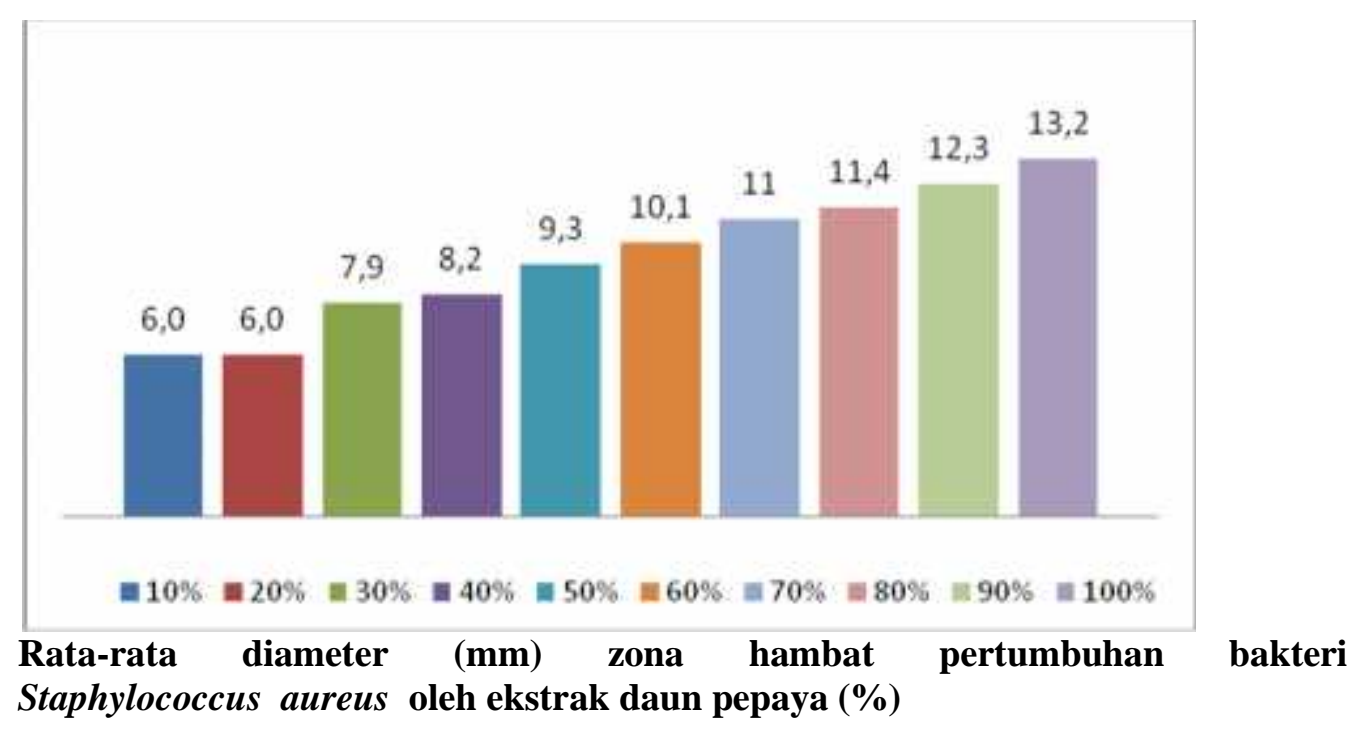

Ekstrak daun pepaya konsentrasi $10 \%$ dan $20 \%$ belum dapat menghambat pertumbuhan bakteri Staphylococcus aureus, sedangkan pada konsentrasi 30-100\% mampu menghambat pertumbuhan bakteri Staphylococcus aureus dengan rata-rata diameter zona hambat $7,9 \mathrm{~mm}$ sampai dengan 13,2 mm. Hasil uji ANOVA didapat hasil $\mathrm{F}$ hitung yaitu 28,93. Artinya $\mathrm{F}$ hitung $\mathrm{F}$ tabel dengan taraf kesalahan 5\% dan $1 \%$, hal ini menunjukkan bahwa ekstrak daun pepaya (Carica papaya L.) berpengaruh terhadap pertumbuhan bakteri Staphylococcus aureus, sehingga dilanjutkan pada uji beda nyata terkecil. Hasil uji BNT ekstrak daun pepaya terhadap bakteri Staphylococcus aureus didapatkan bahwa masing-masing konsentrasi berbeda sangat nyata dalam menghambat pertumbuhan bakteri, kecuali konsentrasi $10 \%$ dan $20 \%$.

Hasil uji daya hambat ekstrak daun pepaya (Carica papaya L.) terhadap pertumbuhan bakteri Escherichia coli dapat dilihat pada grafik batang di bawah ini. 


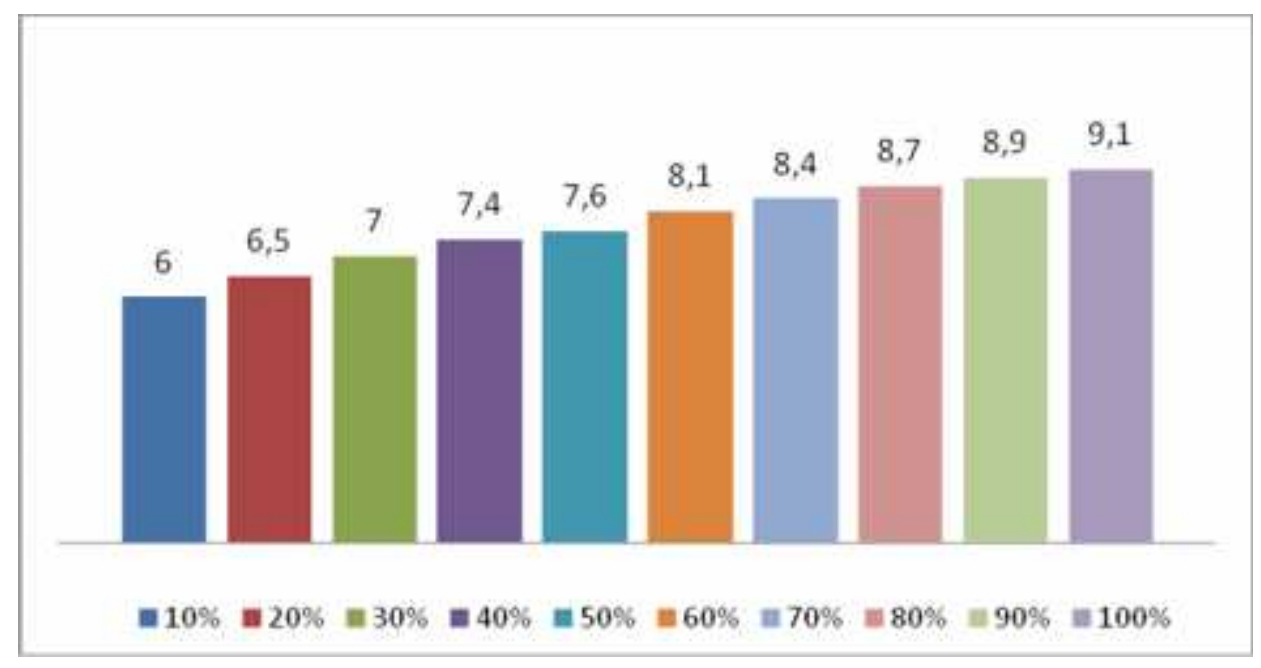

\section{Gambar 2. Rata-rata diameter $(\mathrm{mm})$ zona hambat pertumbuhan bakteri Escherichia coli oleh ekstrak daun papaya (\%)}

Ekstrak daun pepaya konsentrasi $10 \%$ belum dapat menghambat pertumbuhan bakteri Escherichia coli, sedangkan pada konsentrasi $20 \%$ sampai $100 \%$ mampu menghambat pertumbuhan bakteri Escherichia coli dengan rata rata diameter zona $6,5 \mathrm{~mm}$ sampai dengan 9,1 $\mathrm{mm}$.

Hasil uji ANOVA didapat hasil $F$ hitung yaitu 316,4 , artinya $F$ hitung $F$ tabel dengan taraf kesalahan 5\% dan $1 \%$. Hal ini menunjukkan bahwa ekstrak daun pepaya (Carica papaya L.) berpengaruh terhadap pertumbuhan bakteri Escherichia coli, sehingga dilanjutkan pada uji beda nyata terkecil. Hasil uji BNT ekstrak daun pepaya terhadap bakteri Escherichia coli didapatkan bahwa masingmasing konsentrasi berbeda sangat nyata dalam menghambat pertumbuhan bakteri, kecuali konsentrasi $10 \%$.

\section{PEMBAHASAN}

Dalam penelitian ini diketahui bahwa ekstrak daun pepaya dapat menghambat pertumbuhan bakteri Escherichia coli maupun bakteri Staphylococcus aureus. Ekstrak daun pepaya konsentrasi $10 \%$ belum dapat menghambat pertumbuhan bakteri Escherichia coli karena tidak terbentuk zona hambat disekitar disk, sedangkan pada konsentrasi $20 \%$ sampai $100 \%$ mampu menghambat pertumbuhan bakteri Escherichia coli dengan rata-rata diameter zona 6,5 mm sampai dengan 9,1 $\mathrm{mm}$.

Terhadap bakteri Staphylococcus aureus, ekstrak daun pepaya konsentrasi $10 \%$ dan $20 \%$ belum dapat menghambat pertumbuhan bakteri Staphylococcus aureus, sedangkan pada konsentrasi $30 \%$ sampai $100 \%$ mampu menghambat pertumbuhan bakteri Staphylococcus aureus dengan rata-rata diameter zona 7,9 mm sampai dengan $13,2 \mathrm{~mm}$.

Hasil penelitian ini tidak sejalan dengan hasil penelitian Oladimeji (2007) yang mendapatkan zona hambat pertumbuhan bakteri Escherichia coli sebesar $10 \mathrm{~mm}$ pada konsentrasi ekstrak daun pepaya $1,5 \%$ dan $11 \mathrm{~mm}$ pada konsentrasi ekstrak daun pepaya 3\%. Dan mendapatkan zona hambat pertumbuhan bakteri Staphylococcus aureus sebesar $13 \mathrm{~mm}$ pada konsentrasi ekstrak daun pepaya $1,5 \%$ dan 15 mm pada konsentrasi ekstrak daun pepaya 3\%. Perbedaan ini dapat disebabkan karena beberapa hal, seperti perbedaan varietas daun pepaya, dan metode ekstraksi yang digunakan (Soranta, 2009).

Secara statistik, didapatkan bahwa F hitung $\mathrm{F}$ tabel pada pengaruh ekstrak daun pepaya terhadap bakteri Escherichia coli maupun bakteri Staphylococcus aureus. Hal ini menunjukkan bahwa ekstrak daun pepaya (Carica papaya L.) mempunyai pengaruh terhadap pertumbuhan bakteri Escherichia coli maupun bakteri Staphylococcus aureus.

Rata-rata diameter zona hambat yang terbentuk oleh ekstrak daun pepaya terhadap bakteri Escherichia coli lebih kecil dibandingkan terhadap bakteri Staphylococcus aureus, hal ini disebabkan bakteri Escherichia coli merupakan bakteri gram negative dimana dinding selnya mengandung lipid lebih banyak (11-22\%) daripada bakteri gram positif (1-4\%). Kandungan lipid yang tebal pada bakteri Escherichia coli menyebabkan sulit masuknya ekstrak daun pepaya kedalam sel bakteri, sehingga didapatkan 
zona hambat yang lebih kecil jika dibandingkan bakteri Staphylococcus aureus.

Hasil penelitian ini sejalan dengan hasil penelitian Anggraini (2013), yaitu tidak ada zona hambat pada konsentrasi $10 \%$, dan didapatkan zona hambat pertumbuhan bakteri Escherichia coli oleh ekstrak daun pepaya mulai dari konsentrasi 25-100\%. Semakin tinggi konsentrasi ekstrak daun pepaya, maka semakin besar zona hambat yang terbentuk. Besarnya diameter zona hambat yang terbentuk disebabkan kandungan zat antibakteri yang lebih banyak pada konsentrasi yang lebih tinggi.

Terbentuknya zona hambat pertumbuhan bakteri menunjukkan bahwa ekstrak daun pepaya memiliki senyawa aktif antibakteri. Hasil analisis fitokimia daun pepaya oleh Suresh et al. (2008), didapatkan bahwa daun pepaya mengandung senyawa aktif seperti alkaloid karpain, antraquinon, saponin, steroid, tanin, dan triterpenoid. Senyawa aktif tersebut bersifat sebagai antibakteri. Senyawa aktif pada daun pepaya yang berperan dalam menghambat pertumbuhan bakteri adalah tocophenol dan alkaloid karpain. Tocophenol merupakan senyawa fenol yang ada di tanaman pepaya, sedangkan alkaloid karpain termasuk golongan senyawa alkaloid.

Mekanisme kerja zat aktif sebagai antibakteri dengan cara meracuni protoplasma, merusak dan menembus dinding sel bakteri, selain itu dapat mengendapkan protein sel bakteri. Senyawa fenol mampu menginaktifkan enzim esensial di dalam sel bakteri, walaupun dengan konsentrasi rendah. Senyawa fenol mampu memutuskan ikatan peptidoglikan pada dinding sel, yaitu dengan cara merusak ikatan hidrofobik komponen membran sel (seperti protein dan fosfolipida) serta larutnya komponenkomponen yang berikatan secara hidrofobik yang akan berakibat meningkatnya permeabilitas membran, hal ini menyebabkan kebocoran sehingga keluarnya isi sel. Terjadinya kerusakan pada membran sel mengakibatkan terhambatnya aktivitas dan biosintesis enzim-enzim spesifik yang diperlukan dalam reaksi metabolisme.

Alkaloid karpaine memiliki gugus basa yang dapat bereaksi dengan DNA bakteri. Reaksi ini akan merusak DNA bakteri sehingga menyebabkan rusaknya inti sel bakteri. Kerusakan sel membuat bakteri tidak mampu melakukan metabolisme sehingga mengalami lisis, dengan demikian bakteri menjadi inaktif dan hancur.
Senyawa alkaloid merupakan golongan senyawa aktif tumbuhan terbesar. Robinson (1998) menyatakan bahwa alkaloid dapat mengganggu terbentuknya komponen penyusun peptidoglikan pada sel bakteri, sehingga lapisan dinding sel tidak terbentuk secara utuh dan menyebabkan kematian pada bakteri.

Flavonoid bekerja sebagai inhibitor yang akan menghambat replikasi dan transkripsi DNA bakteri. Flavonoid dapat berikatan dengan protein bakteri ekstraseluler dan dapat melarutkan dinding sel bakteri.

Flavonoid merupakan senyawa metabolit yang sering ditemukan pada tumbuhan. Salah satu peran flavonoid bagi tumbuhan adalah sebagai antimikroba dan antivirus, sehingga tumbuhan yang mengandung flavonoid banyak dipakai dalam pengobatan tradisional (Robinson, 1998). Senyawa ini merupakan antimikroba karena kemampuannya membentuk kompleks dengan protein ekstraseluler terlarut serta dinding sel mikroba. Flavonoid yang bersifat lipofilik akan merusak membran mikroba. Flavonoid bekerja sebagai inhibitor Topoisomerase tipe II yang akan menghambat replikasi dan transkripsi DNA bakteri dan dapat berikatan dengan protein bakteri yaitu protein ekstraseluler dan terlarut serta dinding sel bakteri (Anggraini, 2013).

Daun pepaya juga mengandung asam organic seperti lauric acid, caffeine acid, gentisic acid dan ascorbic acid, yang dapat menurunkan $\mathrm{pH}$ intrasel bakteri sehingga sel bakteri tidak dapat berkembang biak.

\section{SIMPULAN}

Simpulan dari hasil penelitian ini yaitu ekstrak daun pepaya (Carica papaya L.) dapat menghambat pertumbuhan bakteri Escherichia coli pada konsentrasi $20 \%$ sampai $100 \%$ dengan rata-rata diameter zona $6,5 \mathrm{~mm}$ sampai dengan 9,1 mm. Sedangkan terhadap bakteri Staphylococcus aureus dapat menghambat pertumbuhan pada konsentrasi $30 \%$ sampai $100 \%$ dengan rata-rata diameter zona $7,9 \mathrm{~mm}$ sampai dengan $13,2 \mathrm{~mm}$.

Tidak didapatkan konsentrasi ekstrak daun pepaya (Carica papaya L.) yang efektif dalam menghambat pertumbuhan bakteri Escherichia coli maupun bakteri Staphylococcus aureus, bila dibandingkan dengan rata- rata diameter zona hambat kontrol positif (antibiotik Chlorampenicol $30 \mathrm{mcg}$ ). 


\section{DAFTAR PUSTAKA}

Anggraini ND., Roza M Rodesia. Fitmawati. 2013. Aktivitas AntibakteriEkstrak Daun Pepaya (Carica papaya L.) terhadap E. Coli dan S typhi. Biologi FMIPA UR.

Ardina, Yustine. 2007. Pengembangan Formulasi Sediaan Gel Anti jerawat Serta Penentuan Konsentrasi Hambat Minimum Ekstrak Daun Pepaya (Carica Papaya A Linn). Master Theses (abstract).

Duke, J. A. 2009. Dr. Duke's Phytochemical and Ethnobotanical Databases. http://www.arsGrin.Gov/Duke/ (Diakses pada 19 Mei 2015).

Gunawan, Didik., Sri Mulyani. 2004. Ilmu Obat Alam (Farmakognosi). Jilid 1. Jakarta: Swadaya.

Jawetz, E., Melnick, J.L., dan Adelberg, E.A. 2005. Mikrobiologi Kedokteran. Jakarta: Salemba Medika.

Robinson, T. 1995. Kandungan Organik Tumbuhan Tinggi. Bandung: ITB.

Soemarno. 2000. Isolasi dan Identifikasi Bakteri Klinik. Yogyakarta: Akademi Analis Kesehatan Yogyakarta.

Soranta, Eko Wahyu. 2009. Aktivitas Antibakteri Ekstrak Etanol Daun Pepaya (Carica Papaya L) terhadap Escherichia Coli dan Staphylococcus Aureus Multiresisten
Antibiotik. Skripsi. Fakultas Farmasi. Universitas Muhammadiyah Surakarta. Surakarta.

Suresh K, Deepa P, Harisaranraj R, Vaira Achudhan V. 2008. Antimicrobial and Phytochemical Investigation of the leaves of Carica Papaya L., Cynodondactylon (L.)Pers., Euphorbia hirta L., Meliaazedarach L. and Psidiumguajava L. Ethnobotanical Leaflets 12; 1184-91. http://opensiuc.lib.siu.edu/cgi/viewcontent. cgi (Diakses pada 15 Mei 2015)

Tim Karya Tani Mandiri. 2011. Pedoman Bertanam Pepaya. Bandung: CV Nuansa Aulia.

Widiastomo, Bobby Wahyu, Sri Winarsih, dan Onggun Napitupulu. 2012. Efek Antimikroba Ekstrak Etanol Daun Pepaya (Carica Pepaya L) terhadap Bakteri Shigella Dysenteriae Kode Isolat 2312-F Secara In Vitro.

Yusha'u, M., Onuorah, F.C. And Murtala, Y. 2009. In-Vitro Sensitivity Pattern Of Some Urinary Tract Isolates Carica Papaya Extracts, Bayero Journal Of Pure And Applied Sciences. 2(2): 75-78. http://www.ajol.info/index.php/bajopas/iss ue/view/7963 (Diakses pada 30 Mei 2015). 